\title{
Tantangan Kompleksitas Manajemen Cedera Ledakan Bom: Pengalaman Dari Rumah Sakit Swasta Tipe B Surabaya
}

\author{
The Challenges in Complexity Management of Bomb Blast Injuries: An \\ Experience from Type B Private Hospital Surabaya
}

\author{
A.K. Wisnu Baroto Sutrisno Putro ${ }^{\circledR *}$, Prananda Surya Airlangga** ${ }^{*}$ Eddy Rahardjo ${ }^{* *}$ \\ "Staf Medis Kamar Bedah, RSK St. Vincentius a Paulo, Surabaya, Indonesia \\ ${ }^{* *}$ Departemen Anestesiologi dan Terapi Intensif, Fakultas Kedokteran Universitas Airlangga, \\ Surabaya, Indonesia \\ ${ }^{\otimes}$ Korespondensi: dr_wisnubarata@yahoo.co.id
}

\begin{abstract}
Background: Across the globe, bombing cases have been increasing in number as a method of terrorism. Blast is the most common cause of injury to the victim. On Sunday, May 13, 2018, three bombs exploded in three churches in Surabaya. Reportedly, there were a total of 43 victims with 13 sudden deaths.

Case: Three cases of bombing victims were reported. All cases were burns of more than $50 \%$ total body surface area. The first and the third case included inhalation injury which required intubation with ventilator support. In all cases, resuscitation based on Baxter formula and prompt burn debridement were performed. Metal debris were found on the first and third patients. The first patient died 20 hours after the explosion. The second and third patients survived subsequent to treatment in Intensive Care Unit (ICU) for 10 and 29 days, respectively.

Discussion: Trauma due to bomb explosion has four stages of effects: primary (pressure direct effect), secondary (explosion projectiles effect), tertiary (structure collapse and thrown victims), and quaternary (burns, inhalation injury, exacerbation of chronic diseases). The management of burn patients due to high order explosive trauma is fundamentally similar to common burn, which is based on the step of primary and secondary survey. If thermal trauma of the upper respiratory tract is suspected based on history, early survey and clinical appearance, airway protectionand intubation should be performed immediately. Fluid management is needed in burn cases to maintain tissue perfusion in the early phase of burn shock.

Conclusion: Explosive trauma victims often have a combination of four kinds of trauma (explosive, blunt, penetrating, and thermal). By recognizing the unique features of these injuries, doctors will be able to give better and prompt treatment.
\end{abstract}

Keywords: Baxter formula; bomb explosion trauma; burns; inhalation injury; thermal trauma 


\begin{abstract}
ABSTRAK
Latar Belakang: Di seluruh dunia, kasus pengeboman meningkat dan seringkali dipakai sebagai metode terorisme. Ledakan adalah penyebab paling umum jatuhnya korban. Minggu, 13 Mei 2018, tiga buah bom meledakkan tiga gereja di Surabaya. Dilaporkan ada 43 korban dan telah mengakibatkan 13 orang tewas saat itu juga.

Kasus: Terdapat 3 kasus dilaporkan sebagai korban ledakan bom. Kesemuanya kasus dengan luas luka bakar lebih dari 50\%. Kasus pertama dan ketiga disertai trauma inhalasi sehingga perlu intubasi dan ventilator. Ketiga kasus diresusitasi dengan formula Baxter dan segera mendapatkan tindakan debridement luka bakar. Pada kasus pertama dan ketiga ditemukan debris logam pada bagian tubuh pasien. Kasus pertama pasien meninggal 20 jam pasca ledakan. Kasus kedua dan ketiga tetap bertahan setelah menjalani perawatan di intensive care unit (ICU) masing-masing selama 10 dan 29 hari.
\end{abstract}

Pembahasan: Trauma ledakan bom mempunyai 4 tahapan efek, yaitu primary (efek langsung tekanan), secondary (efek proyektil ledakan), tertiary (structure collapse dan terlemparnya korban), dan quarternary (luka bakar, trauma inhalasi, eksaserbasi penyakit kronis). Penanganan pasien luka bakar akibat cedera high order explosive pada hakekatnya sama dengan penanganan pasien luka bakar umumnya, berdasarkan tahapan primary dan secondary survey. Berdasar riwayat, penilaian awal dan penampakan klinis diduga ada trauma thermal jalan napas atas, proteksi jalan napas dengan intubasi segera dilakukan. Manajemen cairan kasus luka bakar untuk mempertahankan perfusi jaringan fase awal burn shock.

Kesimpulan: Korban cedera ledakan seringkali menunjukkan kombinasi 4 jenis trauma (ledakan, tumpul, tembus dan thermal). Dengan mengenali gambaran unik cedera ledakan, dokter akan lebih baik dan cepat menangani korban.

Kata Kunci: cedera inhalasi; formula Baxter; luka bakar; trauma ledakan bom; trauma thermal

\section{PENDAHULUAN}

Di seluruh dunia, kasus pengeboman meningkat dan seringkali dipakai sebagai metode terorisme. Ledakan adalah penyebab paling umum jatuhnya korban yang dikaitkan dengan terorisme. ${ }^{1}$ Teroris berusaha untuk melukai/membunuh sebanyak mungkin korban. Karena peningkatan risiko dari serangan teroris, penyedia pelayanan kesehatan seharusnya memahami karakter dari suatu ledakan dan jenis trauma yang mungkin terjadi. ${ }^{2}$

Minggu, 13 Mei 2018, tiga buah bom meledak di tiga gereja dalam wilayah
Surabaya. Dinas Kesehatan Provinsi Jawa Timur melaporkan ada 43 korban dan ditangani di rumah sakit tipe $A$ sebanyak 4 orang, rumah sakit tipe B sebanyak 37 orang, dan rumah sakit tipe C sebanyak 2 orang. Ledakan yang diduga bom bunuh diri telah mengakibatkan 13 orang tewas saat itu juga. $^{3}$

Penanganan dan perawatan luka bakar sampai saat ini masih merupakan tindakan kompleks dan menantang karena angka morbiditas dan mortalitas yang masih tinggi. Kematian umumnya terjadi pada luka bakar dengan luas lebih dari 50\% atau 
pada luka bakar yang disertai cedera pada saluran napas dan $50 \%$ terjadi pada 7 hari pertama perawatan (data dari burn unit RSUD Dr. Soetomo).

\section{KASUS}

Kasus 1

Perempuan, Nn. T, 64 tahun, 50 kg, 155 $\mathrm{cm}$ pukul 08.00 WIB terkena ledakan bom di salah satu gereja di Surabaya. Korban dibawa ke rumah sakit swasta terdekat dan mengalami combustio grade II 96\% TBSA. Sesak napas tidak dikeluhkan, tetapi suara mulai serak dengan respiratory rate $28-32 x / m n t$ dan terukur $\mathrm{SpO}_{2} 96 \%$ dengan oksigen nasal $2 \mathrm{lpm}$. Karena curiga terjadi trauma inhalasi, maka pasien segera diintubasi dengan memperhatikan $C$-spine control. Hemodinamik stabil dengan nadi 90-100 $\mathrm{x} /$ menit dan tekanan darah 150/90 mm $\mathrm{Hg}$. Dilakukan pemasangan CVC dan resusitasi cairan berdasar formula Baxter. GCS sebelum intubasi E4M5V6. Folley kateter dipasang untuk pemantauan produksi urin. Diberikan injeksi human tetanus Ig 250 IU i.m. Segera dilakukan debridement cuci luka dengan anestesi umum. Durante operasi ditemukan serpihan debris logam pada beberapa bagian tubuh pasien. Pasien dirawat di ICU support ventilator post operatif. Screening pemeriksaan radiologis thorax dan ekstremitas tidak ditemukan adanya kelainan ataupun fraktur. Pasien mulai dirawat di ICU pukul 14.00 WIB. Mulai pukul 15.00 WIB produksi urin turun sampai anuria pada pukul 18.00 WIB walau telah diberikan injeksi furosemide $20 \mathrm{mg}$ iv bolus. Pukul 22.00 WIB mulai timbul ronchi basal di kedua lapang paru dan muncul pink frothy sputum. Irama EKG berubah dari sinus menjadi $A F$ slow ventricular responses dan hemodinamik masih relatif stabil. Pukul 04.00 WIB pasien cardiac arrest dan setelah diresusitasi selama 45 menit, pasien tidak ROSC.

\section{Kasus 2}

Perempuan, Ny. F, 34 tahun, 60 kg, 155 $\mathrm{cm}$, pukul 08.00 WIB terkena ledakan bom di salah satu gereja di Surabaya. Korban segera dibawa ke rumah sakit terdekat dan diagnosa combustio grade II 60\% TBSA. Tidak didapatkan sesak napas maupun suara serak dengan respiratory rate 24-28 x/mnt dan $\mathrm{SpO}_{2}$ 99\% dengan oksigen nasal 2 lpm. Hemodinamik stabil (100-120 x/menit dan tekanan darah 130/90 mm $\mathrm{Hg}$ ). Segera dipasang CVC dan diresusitasi cairan dengan formula Baxter. GCS E4M5V6. Folley kateter dipasang untuk pemantauan produksi urin. Diberikan injeksi human tetanus Ig 250 IU i.m. Tindakan debridement cuci luka dengan anestesi umum segera dilakukan. Durante operasi tidak ditemukan debris di tubuh pasien. Pasien dirawat di ICU post operatif. Screening pemeriksaan radiologis tidak ditemukan sisa debris, masalah paru, fraktur ataupun kelainan lain. 24 jam pasca ledakan, pasien dicoba diberikan sonde secara bertahap. Hari ke-3, pasien mulai makan minum normal. Pemantauan gula darah rutin. Analgesia menggunakan kombinasi infus paracetamol dan oxycodone. Pasien menjalani perawatan di ICU selama 10 hari. Tindakan debridement cuci luka rutin setiap 3 hari sekali. 
Tabel 1. Hb, albumin, dan gula darah (diringkas dalam perjalanan setiap 3 hari)

\begin{tabular}{ccccc}
\hline Timeline & $\mathrm{H}-0$ & $\mathrm{H}-3$ & $\mathrm{H}-6$ & $\mathrm{H}-9$ \\
\hline Hb & 16,1 & 12,4 & 9,6 & 8,4 \\
Albumin & 3,0 & 2,1 & 3,2 & 3,0 \\
GDA & 147 & 121 & 134 & 129 \\
\hline
\end{tabular}

\section{Kasus 3}

Laki-laki, Tn. A, 38 tahun, $80 \mathrm{~kg}, 170$ $\mathrm{cm}$, pukul 08.00 WIB terkena ledakan bom di salah satu gereja di Surabaya. Korban segera dibawa ke rumah sakit terdekat dan diagnosa combustio grade II $90 \%$ TBSA. Sesak napas tidak dikeluhkan, tetapi suara mulai serak dengan respiratory rate $24-28 \mathrm{x} / \mathrm{mnt}$ dan $\mathrm{SpO}_{2} 96 \%$ dengan oksigen nasal $2 \mathrm{lpm}$. Karena curiga terjadi trauma inhalasi, pasien segera diintubasi dengan $C$-spine control. Hemodinamik stabil (nadi 110$130 \mathrm{x} /$ menit dan tekanan darah 140/100 $\mathrm{mm} \mathrm{Hg}$ ). CVC segera dipasang dan diresusitasi cairan dengan formula Baxter. GCS sebelum intubasi E4M5V6. Folley kateter dipasang untuk pemantauan produksi urin. Diberikan injeksi Human Tetanus Ig 250 IU i.m. Tindakan debridement cuci luka dengan anestesi umum segera dilakukan.
Durante operasi ditemukan beberapa debris logam pada tubuh pasien. Post operatif dirawat di ICU, tube in dengan support ventilator. Evaluasi pemeriksaan radiologis tidak ditemukan adanya debris logam, fraktur ataupun kelainan lain. 24 jam setelah ledakan, pasien mulai diberi nutrisi enteral per sonde bertahap. Memantau gula darah rutin. Target kalori dihitung berdasar modifikasi rumus Harris-Benedict. Untuk sedasi diberikan dexmedetomidine selama 4 hari dan analgesia selama di ICU menggunakan kombinasi infus paracetamol dan oxycodone. Pasien diekstubasi pada hari perawatan ICU ke-24 setelah edema upper airway dipastikan sudah tidak ada dan kondisi paru baik. Masa perawatan di ICU selama 29 hari. Debridement cuci luka rutin setiap 3 hari sekali.

Tabel 2. Setting ventilator, hb, albumin, gula darah acak dan analisa gas darah kasus 3 (diringkas dalam perjalanan setiap 4 hari)

\begin{tabular}{|c|c|c|c|c|c|c|c|}
\hline Timeline & $\mathrm{H}-0$ & H-4 & H-8 & H-12 & H-16 & H-20 & $\mathrm{H}-24$ \\
\hline Mode & PSIMV & PSIMV & PSIMV & PSIMV & PSIMV & SPON & Ekstubasi \\
\hline PEEP & 5 & 8 & 8 & 6 & 6 & 5 & - \\
\hline pH & 7,32 & 7,42 & 7,39 & 7,44 & 7,43 & 7,38 & 7,45 \\
\hline $\mathrm{pCO}_{2}$ & 32,1 & 47,3 & 45,9 & 42,3 & 39,5 & 41,5 & 42,6 \\
\hline $\mathrm{pO}_{2}$ & 221,9 & 210,2 & 172,4 & 133,6 & 141,5 & 118,4 & 116,1 \\
\hline $\mathrm{BE}$ & $-8,5$ & $-6,8$ & $-5,9$ & 5,3 & 4,2 & 3,3 & 5,0 \\
\hline $\mathrm{HCO}_{3}$ & 16,7 & 18,1 & 20,0 & 30,4 & 26,1 & 24,5 & 29,6 \\
\hline $\mathrm{SaO}_{2}$ & $98 \%$ & $99 \%$ & $99 \%$ & $99 \%$ & $99 \%$ & $99 \%$ & $99 \%$ \\
\hline $\mathrm{P} / \mathrm{f}$ ratio & 221,9 & 262,7 & 287,3 & 334 & 353,7 & 394,6 & 386 \\
\hline $\mathrm{Hb}$ & 17,7 & 14,9 & 9,6 & 8,4 & 11,2 & 10,4 & 9,0 \\
\hline Albumin & 2,2 & 2,1 & 2,4 & 2,7 & 2,8 & 3,0 & 3,1 \\
\hline GDA & 139 & 137 & 156 & 139 & 148 & 132 & 135 \\
\hline
\end{tabular}




\section{PEMBAHASAN}

Ledakan menyebabkan perubahan kimia cepat dari padat atau cair menjadi gas bertekanan tinggi yang menekan udara sekitar. Beratnya trauma ledakan berkaitan dengan tipe dari ledakan dan berbanding terbalik dengan jarak dari pusat ledakan. Ledakan diklasifikasikan sebagai high order explosive (HE) dan low order explosive (LE). ${ }^{4} \quad \mathrm{HE}$ menghasilkan gelombang kejut bertekanan tinggi supersonic (misal: TNT, C-4, Semtex, nitrogycerin, triacetone triperoxide dan dinamit). Sebaliknya LE menghasilkan ledakan subsonic tanpa gelombang bertekanan tinggi (misal: bubuk mesiu, bom pipa, dan bom molotov). ${ }^{2}$

Kapolri Jenderal Tito Karnavian menyebut 3 ledakan gereja di Surabaya pada Minggu, 13 Mei 2018 menggunakan bom yang sama, yaitu berbahan peledak triacetone triperoxide (TATP) yang termasuk HE. ${ }^{5}$ Cedera akibat HE dikategorikan dalam cedera primer (akibat gelombang bertekanan tinggi pada permukaan tubuh), cedera sekunder (akibat dari debris atau pecahan bom), cedera tersier (terlemparnya korban akibat angin ledakan), dan cedera kuartener (luka bakar, trauma inhalasi, eksaserbasi dari penyakit kronis). ${ }^{6}$

Head to toe examination untuk evaluasi dampak primer, sekunder tertier dan kuartener ledakan dilakukan pada semua kasus. Terjadi trauma inhalasi (cedera kuartener) pada kasus 1 dan 2 segera diantisipasi dengan dilakukannya tindakan intubasi. Evaluasi atas kemungkinan terjadinya kerusakan pulmoner, blast lung injury (cedera primer) dilakukan X-ray thorax pada semua kasus. Untuk menyingkirkan kemungkinan terjadinya mild traumatic brain injury (cedera tersier) juga dilakukan evaluasi CT Scan kepala post operatif dengan hasil normal pada semua kasus. Kemungkinan adanya cedera abdominal (perforasi, perdarahan, laserasi) yang merupakan cedera primer disingkirkan dengan evaluasi klinis kondisi pasien didukung analisis USG yang semua hasilnya negatif pada semua kasus. $X$-ray menyeluruh dari cervical ke ekstremitas guna evaluasi adanya cedera sekunder berupa sisa debris dan cedera tertier (fraktur) akibat ledakan dikerjakan dengan hasil semua kasus normal.

Suatu ledakan bom konvensional memungkinkan menciptakan banyak pecahan bom dengan initial velocity lebih dari $1.500 \mathrm{~m} /$ detik. Pecahanpecahan bom tersebut bermassa dan berenergi kinetik tinggi yang dapat menyebabkan fraktur ataupun menembus berbagai jaringan lunak. ${ }^{7}$ Penyebab paling sering kematian dalam peristiwa ledakan adalah cedera sekunder yang dihasilkan dari efek pecahan bom. ${ }^{1}$ Pada kasus 1 dan 3 ditemukan banyak pecahan bom di beberapa bagian tubuh pasien. Oleh karena itu, perlu dan telah dilakukan screening mendalam untuk mengidentifikasi lokasi, jumlah dan dampak dari pecahan bom tersebut pada organ-organ vital pasien untuk menentukan perlu tidaknya tindakan penanganan lebih lanjut.

Penanganan pasien luka bakar akibat cedera HE kuartener pada hakekatnya sama dengan penanganan pasien luka bakar pada umumnya, yaitu berdasarkan tahapan primary survey dan secondary survey. ${ }^{8}$ Pada kasus 1 dan 3, ditemukan permasalahan nyata yang berpotensi mengancam jalan napas dengan terjadinya trauma inhalasi sehingga perlu intubasi segera. Hilangnya airway 
patency disebabkan oleh edema mukosa dan jaringan yang biasanya terjadi setelah beberapa waktu resusitasi cairan dimulai. Berdasar riwayat, penilaian awal dan penampakan klinis patut diduga adanya trauma thermal jalan napas atas, proteksi jalan napas dengan intubasi seharusnya dilakukan sebelum terjadi pembengkakan mukosa dan jaringan yang akan membuat intubasi menjadi sulit. $^{9}$

Kasus pertama meninggal setelah 20 jam dari waktu ledakan. Nampak pink frothy sputum dan adanya ronchi basal di kedua lapang paru menunjukkan terjadi pulmonary edema yang kemungkinan disebabkan kerusakan jaringan alveoli paru akibat trauma inhalasi yang menyebabkan nilai ambang edema menurun selain juga dampak dari pemberian cairan masif sebagai upaya resusitasi. Luka bakar sendiri menyebabkan perubahan mikrovaskular berupa peningkatan permeabilitas vaskular yang menimbulkan pergeseran cairan cairan dari intravaskular ke ruang interstitial yang meningkatkan risiko edema, hipovolemia dan hemokonsentrasi. ${ }^{10}$ Terjadinya pulmonary edema menyebabkan hipoksia yang akhirnya mengganggu fungsi cardiac pasien yang nampak dari perubahan irama EKG dari sinus menjadi AF. Akibat kondisi hipoksia lama dan sukar diatasi, pasien akhirnya mengalami cardiac arrest.

Outcome bagus pada kasus 3 dan terutama kasus 2 yang dimungkinkan karena kerusakan organ yang terjadi lebih ringan. Namun demikian tetap diwaspadai terjadinya Blast Lung Injury (BLI) pada kasus 3 berupa Mild BLI berdasar hasil $\mathrm{PaO}_{2} / \mathrm{FiO}_{2}$ 221,9. BLI dikenali pada korban ledakan disertai distress napas dengan adanya butterfly appearance ataupun pneumothorax pada CXR. ${ }^{11}$ Lung protective ventilation merupakan acuan dalam penatalaksanaan pasien trauma ledakan terintubasi. Prinsip lung protective berdasarkan pada protokol ARDS, yaitu low tidal volume $(6-8 \mathrm{ml} / \mathrm{kg} . \mathrm{BB})$, permissive hypercapnea, pemberian PEEP, dan pembatasan plateau pressure kurang dari $30 \mathrm{~cm} \mathrm{H}_{2} \mathrm{O} .{ }^{12}$

Semua kasus telah mendapatkan resusitasi cairan ringer lactate (RL) berdasarkan formula Baxter sejak diterima di unit gawat darurat (UGD). Tujuan resusitasi cairan pada luka bakar adalah untuk mempertahankan perfusi jaringan fase awal burn shock dimana hipovolemia akhirnya bisa terjadi karena ekstravasasi cairan dari kompartemen intravaskular. Baxter menemukan bahwa pasien trauma inhalasi membutuhkan tambahan cairan bila dibandingkan dengan kasus yang lain. Sejumlah besar cairan resusitasi juga berkaitan dengan peningkatan risiko terjadinya komplikasi infeksi, acute respiratory distress syndrome (ARDS), abdominal compartement syndrome dan kematian. ${ }^{13}$

Nutrisi merupakan aspek kritis penatalaksanaan pasien luka bakar. Metabolic rate pasien luka bakar dapat meningkat lebih dari dua kali normal. ${ }^{14}$ Waktu pemberian support nutrisi merupakan faktor penting pada outcome pasien luka bakar berat. Kerusakan mukosa intestinal dan peningkatan translokasi bakterial terjadi setelah luka bakar dan menyebabkan penurunan absorbsi nutrient. ${ }^{15}$ Oleh karena itu, support nutrisi idealnya dimulai dalam 24 jam setelah injury via rute enteral. ${ }^{14}$ Baik pada kasus 2 dan 3, berdasarkan pula pertimbangan bahwa selama observasi hemodinamik stabil, maka nutrisi enteral per sonde mulai diberikan 
secara bertahap 24 jam setelah peristiwa ledakan.

Tujuan utama dukungan nutrisi pada pasien luka bakar adalah memenuhi peningkatan kebutuhan kalori disebabkan status hipermetabolik dan menghindari overfeeding. Indirect Calorimetry merupakan gold standard terkini untuk mengukur energy expenditure, tetapi seringkali keterbatasan peralatan tidak memungkinkan hal tersebut dilakukan. ${ }^{16}$ Untuk menghitung kebutuhan kalori pasien luka bakar dapat digunakan Modified Harris Benedict dengan menambahkan faktor aktivitas dan faktor stress akibat trauma. ${ }^{17}$ Pada kasus 2 dan 3 , untuk hari pertama mulai diberikan dulu 30\% dari target kalori total dan secara bertahap ditingkatkan sampai tercapai target kalori sesuai rumus Modified Harris Benedict dalam waktu 3 hari.

Anemia pasien luka bakar ada 2 tipe, yaitu acute blood loss anemia dan anemia of critical illness. Kehilangan darah akut berkontribusi utama terhadap kejadian anemia pada pasien luka bakar, terjadi pada minggu ke-1 sampai ke- 2 . Anemia of critical illness bertanggung jawab atas penurunan $\mathrm{Hb}$ antar periode pembedahan, selama penyembuhan luka dan pemulihan fase akut cedera disebabkan ketidakseimbangan antara produksi dan destruksi eritrosit. Metode paling efektif koreksi anemia adalah dengan transfusi packed red blood cell (PRC) dengan berbagai kemungkinan komplikasinya. ${ }^{18}$ Pada kasus 2 dan 3, anemia yang terjadi nampak bertipe anemia of critical illness. Transfusi PRC yang telah diberikan pada kedua kasus tersebut berdasarkan kebutuhan fisiologis yang nampak didasarkan vital sign pasien, estimasi kehilangan, evaluasi volume darah, evaluasi klinis dan laboratorium.

Hipoalbuminemia merupakan kondisi klinis umum pada pasien luka bakar dan berhubungan dengan komplikasi yang berkaitan peningkatan cairan ekstravaskular, edema, penyembuhan dan kecurigaan sepsis. Pasien dengan level albumin kurang dari $2 \mathrm{~g} / \mathrm{dL}$ mempunyai risiko mortalitas lebih $80 \% .{ }^{19}$ Level albumin serum juga bisa digunakan sebagai evaluasi beratnya luka bakar dan status nutrisi protein. ${ }^{20}$ Oleh karena itu, pada kasus 2 dan 3 telah dilakukan pemeriksaan berkala level albumin serum dan koreksi atas kondisi hipoalbuminemia bila terjadi. Kontrol glukosa darah salah satu elemen kunci manajemen pasien luka bakar. Pada pasien luka bakar yang kurang dilakukan kontrol glukosa secara signifikan lebih tinggi terjadi insiden bakteraemia/ fungaemia, naiknya katabolisme dan peningkatan mortalitas. Rentang kadar glukosa antara 90 sampai dengan 140 $\mathrm{mg} / \mathrm{dL}$ ideal untuk pasien luka bakar. ${ }^{21}$ Kasus 2 dan 3 telah dilakukan monitoring glukosa darah acak ketat setiap hari. Hiperglikemia yang terjadi diterapi dengan metformin. Metformin menurunkan kadar glukosa seefektif insulin tanpa menyebabkan hipoglikemia. $^{22}$

Setelah fase awal resusitasi, lebih dari $75 \%$ kematian pasien luka bakar berkaitan dengan infeksi. Pencegahan infeksi, pengenalan bila infeksi terjadi dan pengobatan yang tepat merupakan hal yang menantang. Infeksi tersebut dimungkinkan karena rusaknya kulit dan mukosa, adanya jaringan nekrotik dan eksudat serosanguinous, terpasangnya monitor invasif serta gangguan fungsi kekebalan. Guna mencegah infeksi luka diperlukan tindakan debridement agresif dan penggunaan topikal antimikrobial 
sesuai. Terapi topikal tidaklah cukup karena tidak efektif untuk menembus jaringan yang rusak. Pilihan antibiotik tergantung predominan flora yang kemudian disesuaikan dengan hasil kultur dan tes sensitivitas. ${ }^{23}$

\section{KESIMPULAN}

Manajemen cedera ledakan bom merupakan hal yang sangat menantang sejak frekuensinya meningkat di seluruh dunia. Korban cedera ledakan seringkali menunjukkan kombinasi dari 4 jenis trauma (ledakan, tumpul, tembus dan thermal). Dengan mengenali gambaran unik dari cedera ledakan ini, dokter akan lebih baik dan lebih cepat dalam menangani korban. Dengan memahami kompleksitas manajemen pasien luka bakar efek ledakan bom, dokter akan dapat mengurangi morbiditas dan mortalitas korban.

\section{DAFTAR PUSTAKA}

1. Halpern P, Tintinalli JT, Stapeszynski J, et al. Bomb, blast and crush injuries. Tintinalli's Emergency Medicine: A Comprehensive Study Guide. Edition 7. New York: MacGrawHill Education; 2011.p.38-43

2. Lemonick DM. Bombing and Blast Injuries: a Primer for Physicians. American Journal of Clinical Medicine. 2011;8(3):12-13

3. Pramudiarja ANU. Menkes: Pemerintah Tanggung Biaya Pengobatan Korban Bom Surabaya. [internet] 2018. [cited 2019 Apr 3]. Available from https://health.detik.com/beritadetikhealth/d-4018361/menkespemerintah-tanggung-biayapengobatan-korban-bomsurabaya

4. Explosions and Blast Injuries: A Primer for Clinicians. Centers for
Disease Control and Prevention. [internet] 2003. [cited 2019 Apr 3]. Available from http://www.bt.ede.gov/masscausual ties/explotions.asp

5. Rinanda HM. Kapolri: Bom di Jatim Gunakan 'The Mother of Satan' detikNews. [internet] 2018. [cited 2019 Apr 10]. Available from : https://news.detik.com/berita/40195 05/kapolri-bom-di-jatim-gunakanthe-mother-of-satan.

6. DePalma RG, Burris DG, Champion $\mathrm{HR}$, et al. Blast Injuries. New England Journal of Medicine. 2005; 352: 1335-42

7. Almoghy G, Makori A, Zamir O, et al. Rectal Penetrating Injuries from Blast Trauma. The Israel Medical Association Journal. 2002; 4: 558

8. Rahardjo P. Pengelolaan Luka Bakar dari Sudut Pandang Anestesiologi. Surabaya: Departemen Anestesiologi \& Reanimasi FK UNAIR-RSUD dr. Soetomo; 2013

9. Gregoretti C, Decaroli D, Stella M, et al. Management of blast and inhalation injury. Breathe. 2007; 3(4): 365-73

10. Guilabert P, Usua G, Martin N, et al. Fluid resuscitation management in patient with burns: update. British Journal of Anaesthesia. 2016; 117(3): 284-96

11. Pizov R, Eden AO, Matot I, et al. Blast Lung Injury from an explosion on a civilian bus. Chest. 1999; 115: 165-172

12. Mackenzie IMJ, Tunnicliffe B. Blast injuries to the lung: epidemiology and management. Philosophical Transaction of The Royal Society B. 2011; 366: 295299

13. Haberal M, Abali AES, Karakayali $\mathrm{H}$. Fluid management in major burn 
injuries. Indian Journal of Plastic Surgery. 2010; 43 (Suppl): S29-S36.

14. Rousseau AF, Losser MR, Ichai C, et al. ESPEN endorsed recommendations: nutritionat therapy in major burn. Clinical Nutrition. 2013; 32(4): 497-502

15. Magnotti LJ, Deitch EA. Burns, Bacterial Translocation, gut barrier function, and failure. Journal of Burn Care and Rehabilitation. 2005; 26(5): 383-91

16. Clark A, Imran J, Madni T, et al. Nutrition and metabolism in burn patiens. Burns \& Trauma. 2017; 5: 11

17. Noer MS. Penanganan Luka Bakar. Surabaya: Airlangga University Press; 2006. 11: p95

18. Posluszny JA, Gamelli RL. Anemia of thermal injury: Combined acut blood loss anemia and anemia of critical illness. Journal of Burn Care and Research. 2010; 31(2): 229-242

19. Becerra OAA, et al. Serum albumin level as a risk factor for mortality in burn patient. Clinic; 2013. 68 (7): 940-945
20. Guisado JP, Padilla JMH, Rioja LF, et al. Serum albumin levels in burn people are associated to the total body surface burned and the length of hospital stay but not to the initiation of the oral/enteral nutrition. International Journal of Burn and Trauma. 2013; 3(3):159163

21. Kamolz LP, Pieber T, Juttner FMS, et al. Optimal blood glucose control in severely burned patients: a long way to go, but one step closer. Critical Care. 2013; 17: 1005

22. Jeschke MG, Abdullahi A, Burnett $\mathrm{M}$, et al. Glucose control in severely burned patients using metformin: an interim safety and efficacy analysis of a phase II randomized controlled trial. Annals of Surgery. 2016; 264(3): 518-27

23. Ansermino M, Hemsley C. ABC of Burns: Intensive care management and control of infection. Clinical Review. British Medical Journal. 2004; 329: 220-223 